\title{
The Values of Balogo Traditional Game as The Source of Social Science Education (IPS) Learning
}

\author{
Syaharuddin \\ Social Science Education \\ Faculty of Teacher Training and Education \\ Universitas Lambung Mangkurat \\ Banjarmasin, Indonesia \\ syahar@unlam.ac.id
}

\author{
Nasruddin \\ Geography Education \\ Faculty of Teacher Training and Education \\ Universitas Lambung Mangkurat \\ Banjarmasin, Indonesia \\ M. Fajar Rivanny \\ History Teacher of Madrasah Aliyah Negeri Tanah Laut \\ Pelaihari, Indonesia
}

\begin{abstract}
The rapid development and advancement of technology that creates digital-based games has displaced traditional games. Games have replaced the traditional game that is identical to the values of life, such as the value of sportsmanship, competitive value, and the value of cooperation. Balogo is one of Banjarese traditional games which has these values. Balogo as traditional game that belongs to urang Banjar is a culture that should be preserved by the people who have diverse cultures (multicultural). The objective of this research is to explore the values of balogo traditional game in Banjarese community in Pelaihari, Tanah Laut as a source of social study learning. The research method employed was qualitative research. The subjects were Banjarese people in Pelaihari who know the balogo traditional game and the academicians. The sources of data were the interview, observation and study of literature. The analysis techniques were: (1) data reduction, (2) data presentation, and (3) verification/conclusion. The triangulation and members check were used to check the validity of the data. The results showed that the balogo traditional game has the values of life, such as; sportsmanship values (honesty), cooperation (kayuh baimbai), competitive value, creativity and arts, social and economic values that appear on the equipment of the game, game procedure, and interaction among the groups who play balogo. These values have the potential to build the character of the nation through social science education (IPS) in schools at the level of basic education (SMP / MTs).
\end{abstract}

Keywords - values, traditional game, balogo, social science education (IPS), learning sources

\section{INTRODUCTION}

Traditional games nowadays have been displaced by the rapid development and advancement of technology that creates digital-based games. Games have replaced the traditional game that is identical to the values of life, such as the value of sportsmanship, competitive value, and the value of cooperation.
According to [1], the original knowledge system like traditional games is a specific culture. It builds the basis for people's lives. Through the traditional games, children will know their environment and acquire life skills.

Functionally, a traditional game has the ability to train someone in solving problems. Social skills have the potential to help a person in solving all the problems of life (Sutton \& Smith, in [2]). Reference [3] state that traditional games (nekeran) have function to focus, respect (achievement) and have confidence. However, [4] highlight the effectiveness of traditional boy-boyan game as a learning medium.

Balogo is one of traditional games remaining in Banjarese community. The word balogo is from the word "Logo" which means playing by using a tool called "logo". The $\log o$ is a coconut shell with a diameter size of about $5-7 \mathrm{~cm}$ and $1-2 \mathrm{~cm}$ thick and mostly made of two bonded layered with asphalt or putty material for its strength and weight. Logo shape varies, and there are also various forms such as bidawang (fleeced), biaku (turtle), triangle, kite, leaf and round shape. Despite the logo, the game is also equipped with a panapak such as measles or insipid. Panapak as stick with about $40 \mathrm{~cm}$ in length is used as a hitter that serves to launch the $\log o$ and knock down the opponent. In the past, this could be played by individuals and teams.

Balogo game in Banjarese community is full of the life values, such as competitive value (competition), honesty (sportsmanship), and cooperation. These values have a strategic function in social science education (IPS) in order to establish the character of the nation (nation and character building). Social science education (IPS) based on the values can be extracted from the local culture (Banjar), such as balogo.

According to [5], social science education (IPS) has purpose that is " ... helping students to develop the knowledge, skills, attitude, and value needed to participate in the civic life 
of reviews their local communities, the nation, and the world. He reiterated that the main goal of social studies is "... to prepare citizens who can make-reflective decision and participate successfully in the civic life of reviews their communities, nation, and the world. Goals in four categories contribute to this major goals: (1) knowledge, (2) skills, (3) the attitude and values, and (4) citizen action [5].

Banks' assertion of the purpose of social science education (IPS) that this study is very useful for learners in shaping the knowledge, skills, behavior and values, and social action. Besides, the success of learners in their social life should start from the nearest life, that is the environment. This concept will be developed in this research through expanding community approach or in [6] concept called as "expanding environment approach". Balogo is a Banjarese traditional game which is currently emerging in Pelaihari played by children and adults.

The strength of traditional games, which have the potential to develop social skills to face globalization era, is increasingly approaching its extinction. The rapid development of technology and information are some of the causes of its extinction, and it needs an exact formulation to restore the traditional game in order to have a place in the heart of society through the social science education (IPS) at schools. The optimization of formal education in integrating the original knowledge into the national curriculum may be the answer [1]. The implementation at school levels can be through the development of certain lessons, such as sports and health.

On the other hand, the nation's current condition gives an overview which is weak against the strengthening of social values, and a shift of ethical values in the life of the nation, such as the low appreciation of the value of culture and language, the value of social solidarity, consensus, kinship, polite courtesy, honesty, ashamed feeling, and love for the homeland [7].

In the context of social science education (IPS), local culture has not been optimized as a source of learning social science education (IPS). Experiences of social democracy values have not been accustomed by involving the students and the school community in a variety of classroom activities and school [4]. The students feel little functional and quality social science education (IPS) in social life. The information obtained from the text book much different and even contrary to the socio-culture environment [8]. However, [9] states that teacher's ability in preparing the syllabus and lesson plans has not yet showed the peculiarities of the educational unit. This includes culture owned by each region which has uniqueness of each ethnic.

Based on the aforementioned problems, the focus of this research was about values of balogo traditional game in Pelaihari, Tanah Laut and the values would be important to serve as sources in social science education (IPS) in basic education schools (SMP / MTs).

\section{LITERATURE REVIEW}

\section{A. Objective and Characteristics of Social Science Education}

According to [10], there are some objectives of social science education (IPS), namely having the ability to communicate, collaborate and compete in a pluralistic society, locally, nationally, and globally. These objectives can be explored through balogo traditional game. Teamwork system in balogo requires effective communication between the captain and the whole team to win the game.

The characteristics of social science education (IPS) according [9] is the development of value, value analysis and its application to social action. Social issues can be defined as problems that occur in the middle of society that must be solved and it invites the community participation as citizens in finding the solutions. Despite the value-based, social science education (IPS) has another dimension which is the ability to take the right decision (decision making process) against the various social problems faced in the local, national and global areas.

Balogo game has the ability in helping people to practice the social skills, especially the ability to solve the problem (problem based) and take a decision (Decision making). Communications are built among teams in the game in order to win the game which in turn train everyone to make the right decision.

The importance of local-based social science education (IPS) is confirmed by [9], that the source of social science education (IPS) can be obtained from the public, the social and cultural conditions that exist in the local environment of learners. Balogo is typical owned by Banjarese people which is currently played every day by the people and society in Pelaihari, Tanah Laut, and South Kalimantan in general

\section{B. The Values in Social Science Education (IPS)}

The word 'value' comes from the Latin Valere or in ancient French language valoir which means "price". If the word value is connected to an object or perceived from a particular point of view, the value or "price" contains various interpretations. There is a price according to the economic (prices in usability goods), psychology (confidence people), sociology (social norms), anthropology (cultural), political (power or interest), or religion (religious belief) [14].

According to Franke in [3], value includes the field study of philosophy. The term is defined as the value in the philosophy of the worth or goodness, and the verb that means a certain psychological measures in assessing or making judgments.

Based on Rokeach as quoted from [11], value is an enduring belief that becomes a reference for how to behave or the ultimate goal of existence (mode of conductor and-state of existence) which is the preference of the better conception (that is personally or socially preferable).

Planting the value is the spirit of education. Therefore, the educational patterns should develop and urge the students to the values of truth, honesty, virtue, wisdom and compassion as universal values shared by all religions and the nations 
everywhere. Education has function to strengthen faith and piety in specific according to religious beliefs. In summary, every learning should always be integrated according to values in order to produce students who have personality and can integrate their knowledge with the values that are believed to solve various problems of life and human life system. Balogo traditional game in Pelaihari has a strategic function of the implantation of the character and as a source of material development of social science education (IPS) at the basic education level (SMP/MTs).

\section{Local Wisdom As a Social Science Education (IPS) Learning Source}

Local knowledge or local wisdom in a foreign language conceived as a policy or local knowledge or local intelligence "local genious". According to [11], local wisdom is the human intelligence possessed by certain ethnic groups obtained through community experience. According [12], local wisdom is a tool of knowledge and good practices derived from the previous generations as well as from the experience of dealing with the environment and other people who belong to a community somewhere.

Banjarese society in Pelaihari district, Tanah Laut, have values in playing logo, namely competitive values, teamwork, and communication. Social science education (IPS) based on local wisdom can be used as a medium to preserve the potential of each region. Local wisdom must be developed from the potential of the region. The regional potential is the potential of specific resources owned by a particular region. Balogo traditional game is the Banjarese cultural heritage that contains the values of life. Therefore, it should be preserved for the young generation.

\section{METHOD}

This research used a qualitative approach that aimed to describe the values of balogo traditional game in Pelaihari district, Tanah Laut in order to serve as a source of social science education (IPS) learning. The data collection techniques in this study included: (1) interview; (2) observation; and (3) documentation study. The interviews were conducted with the local people and the academicians who understand balogo. The observations were made to determine the activity in balogo traditional game. The researcher observed twice, in Benhil area and in the Ranggang village. The documentation study was conducted on primary or secondary references, either in the form of books, research articles and journals related to traditional games. The data were analyzed based on the model of [13], namely (1) data collection; (2) data reduction; (3) data presentation; (4) conclusions and verification. The validity of the data test was based on [14], which was triangulation by using the widest possible sources such as methods, previous studies, and theories that provide corroborative evidence. Triangulation is also procedure that varies in data collection [15]. The other one was member checks. The researcher gathered the views of informants about the credibility of the findings and the interpretations. In practice, the researcher met the informants for clarification and confirmation about balogo, including the function of captain, a touch of art in the logo and campak, and some things about the rules of the game

\section{RESULT AND DISCUSSION}

The study of balogo traditional game is full of the potential values of life in building the national character through learning social science education (IPS) in basic education schools (SMP / MTs). According [16], traditional games have potential in promoting awareness of identity and create a sense of pride about people's own culture. Building the awareness of identity is important in the middle of the globalization swift that is supported by technological developments and information that have both positive and negative effects.

In relation to local content in the national curriculum for the formation of students' identity and cultural awareness, Reference [16] asserts that the national curriculum should integrate the cultural heritage in learning at schools. In fact, the local culture is not discovered and integrated deliberately by teachers yet, especially by the social science education (IPS) teacher at schools that potentially make alienation of the students toward their own culture, and in the end their identity will be lost.

Balogo traditional game has been currently booming in Pelaihari district and almost in the entire village and RT (Neighborhood) in Tanah Laut regency since the last two years. It becomes an attraction to be studied when people especially school aged children (elementary and junior high school) in Pelaihari and in Indonesia in general are in "fever" of online games, gadgets and social media. This condition affects are not only the great cultural heritage loss, such as balogo, but also contribute to the identity loss as a cultured nation.

The observation on and interviews with the several $\log o$ players and the people who have once played logo (between 1970-1980) were conducted on several aspects, namely game equipment, which consists of logo and campah or campak, field and how to create logo and strategy in playing the logo. Based on the results of the study, it was found that there were values of life that have the strategic function to the formation of national character through IPS education in school. The values are as follows: (1) the value of sportsmanship (honesty), (2) the value of cooperation/mutual assistance (kayuh baimbai), (3) the value of creativity and the arts, (4) the value of competitive spirit, (5) social value, and (6) economic value. These values will be explained and supported by previous concepts and research results related to the traditional game.

The values of sportsmanship (honesty) in any traditional game are almost always presented in different forms. Reference [17], in his research, explained that there was a very significant influence of gobag sodor game on the agility and reaction speed, and it also trained the cognitive, competitive spirit and sportsmanship.

In balogo, a player must uphold the values of sportsmanship, which are (1) starting "membuah" (hitting logo) on the start line that has been determined; (2) carefully calculating own points and "opponent" points; (3) willing to 
comply with the captain's order as the person who has been given the task of regulating the game along with the committee; (4) willing to accept and run all the rules that have been made by the committee; (5) being ready to accept the defeat and feeling humble or not arrogant for the winners, so it will not lead to an attitude of revenge.

Those five values of sportsmanship have potential in the development of learning resources of social science education (IPS). Internalization of those values through social science education (IPS) is expected to have implications on the forming of students' characters so that the goals of social science education (IPS) to form good citizens can be achieved [18].

Sportsmanship is the key to almost all modern games including sports, like football, basketball, badminton and so on. The ability of someone to be sportive in playing game will give effects on their life in the future, that life must be honest. Honesty will affect a person's social life.

The attitude of cooperation in which communication is established becomes an attitude that is almost always present in every game. According [19], the rule of the game consists of more than one person. In this game, a child will inevitably communicate with other children. Reference [18] describes that the values embodied in the traditional game gobak sodor have social aspects which include the values of social skills, cooperation, discipline and solidity.

The value of cooperation is also showed in the balogo game. Kayuh baimbai principle or pedaling together to achieve a shared vision that is winning the game appears in this game. This game is played in groups. Balogo first is played individually between 3-5 people. Nowadays, this game has been modified to some extents, such as the number of players, conducted in groups, the more various ages of group participants, the basic material of the logo, the shape and size of the field, the punishment, and so on.

If the previous numbers of players were between 3-5 people and played individually, now it is done in groups with the average of 10 people led by a "captain". The captain's job is to organize the game. He is the one who sets the game strategy. "Intelligence" of a captain in setting the game strategy will affect to the chance of the total points that can be earned and it is vice versa. Therefore, the captain has an important role in this game.

There are many forms of cooperation that appear in balogo game. For example, the player obeys the captain's orders when the player starts hitting the logo pasang. The members of the group may only hit the logo after receiving an order from the captain. Usually, it is done by mentioning a specific number of the logo to indicate the batting number to hit the logo pasang. The other mutual assistances is baurunan or bakumpulan (collecting) registration funds. Some participants from student category explain that they had joined the race by paying the registration as much as Rp. 300.000. The amount of the money is big enough for students. Therefore, through urunan with fellow team, they can come to play logo. Moreover, the broader form of cooperation is assisting each other in implementing balogo competitions or just friendly matches between villages. The good distribution of the tasks for each person on both of those activities would produce good activities as well.

Cooperation is an attitude that should be part of one's life to achieve a better quality of life. Cooperation or mutual assistance in its local language is called kayuh baimbai. It is included in the social science education (IPS) (Permendiknas No. 22 of 2006) and is a very basic form of interaction [20]. Cooperation is also part of the attitude in mutual cooperation. Mutual assistance can be seen from a variety of Banjarese people's activities, such as ceremony of bahaul in the Andhika village of Tapin. This activity is similar to mutual assistance which starts from batuturukan activity, bubuhan pangayuhan activity, bubuhan pangawahan and bubuhan lalawatan [21].

Reference [22] asserts that the culture of mutual cooperation in this country is related to the issue of the nation future. Thus, it is very important that the culture should be passed down to the younger generation to be competitive in the global era. Making balogo game as a source in IPS learning has effectiveness towards the internalization of mutual assistance values.

The traditional game of balogo is identical to the cooperation (kayuh baimbai) and is a part of the social skills in the context of social science education (IPS) [18]. This is in line with the opinion of [4], in her study of traditional hopscotch game. According to her, there are some social skills in playing the game, namely competition, negotiation, communication, and empathy. In line with the opinion of [23], in their study on benthic game, benthic traditional game can train character of teamwork.

Balogo game has good competitive values both in its old patterns and in its modified pattern. The important competitive values are developed in social science education (IPS) because today is an era of global competition. This era requires a strong mental attitude that can be used to be able to compete with other nations. Only by having a strong mental attitude can we survive in the era of this free competition. The loss of this attitude in society can give the potential impact on the low competitiveness of the nation in this century.

Reference [4] research results on the traditional game of engklek, demonstrated that in the game, there were social skills, such as competition, negotiation, communication, and empathy. The establishment of competitive spirit in balogo game can be seen by the urge to win in every game and friendly matches. Second, competing in having campah and $\log o$ with the better basic material with strong art polish can make the game interesting and attract the viewers. It is because good quality campak and logo have chance to win every game. In addition, there are many strategies that run when competing. The strategies can be varied, for example, determining the first hitter, second, and so on by a captain. The second strategy is to learn the correct hitting technique to produce a good blow. The third strategy is to select the better base material of logo and campah. The last strategy is to give a touch of art to the logo and campak so that uplifting the spirit during the match and might affect an opponent during a match. 
A touch of artistic value and creativity also appear on the logo and campah of each player. There are various forms of the logo, which has shape like biku (turtle), kites, triangle, round, leaves and hearts. The length of logo is for about $9 \mathrm{~cm}$, the width is about $11 \mathrm{~cm}$ and the thickness is about $2 \mathrm{~cm}$ while the government has its own version in which the width is of at least $8-10 \mathrm{~cm}$, and maximum 10-12 cm. Logo and campak get a touch of art based on the taste or likes of each player. Among them, there are campah shaped like cobra head, head man of a certain character, a certain engraving campah variation, campah with puppet ornate, and so on. The logo which is used as undas is different and seemed to have the variation of its art value based on the taste of the owner.

The high level of art certainly has a high value as well. Economically, a campak which is made from the raw material of superior wood and campak headdress that looks complicated have very high "price" as well. The wood types of campak can be from palas, pinang, palam and paring. In general, the type of paring (bamboo) becomes the public's choice. Several campak are fitted with the price of Rp. 150.000. This price can be said high because it has been touched with high artistic value.

The balogo game provides art sense for the players. Art will give a positive impact to every players' soul. A touch of art will affect the tranquility in the soul. The tenderness of heart and soul belong only to art enthusiasts. Artistic values in balogo will give a positive impact for the community to make life more beautiful and meaningful.

Social values in the balogo game is the occurrence of the social interaction that is quite intense among the players, spectators, merchants, parking guard, the committee even the officials who helped to sponsor. This interaction gives a social impact, namely the growing social, warm, harmonious and friendly relationship without knowing the differences of tribe, religion, class and other social status. The form of social interaction is the activity of cooperating, shaking hands, talking to each other or even fighting each other [20].

Based on the researcher's observation during watching the balogo game twice in Pelaihari, it seemed like there was no conflict happened such as a protest as an indication of fraud in the game. It can be interpreted that sportsmanship is always held in high esteem value in the balogo game. Another thing is there was no cultural barriers and ethnicity in this game. Although balogo is a typical game belongs to the Banjarese, but Pelaihari people who are multi-ethnic, from Banjarese ethnic as the dominant culture, then the Javanese, Sundanese, Bugis, Arabic and Chinese were very enthusiastic to learn and follow every race carried out either by the local government through the Department of Youth and Sports or those implemented at the initiative of the community in every village in Pelaihari and Tanah Laut regency generally.

The ethnicity typology according to Schermerhorn in [24], has at least a unity of ancestors, has a cultural focus in one or more symbolic elements that state its membership, such as physical features, religious affiliation and beliefs, dialect forms or language, and tribal affiliations. The participation of Chinese ethnic, Arabic, Javanese and some other ethnic groups in the balogo game in almost every village in Tanah Laut is a reflection of a positive interaction among different ethnic groups. This social condition is an opportunity to the government in carrying out and building in all areas of life.

Economic values which are found in the balogo game are an increase in the welfare of society through the opening of food and drink stalls and parking lots around the logo ground on a specific area, which is often used as a place for the tournament (matches between villages), such as Ranggang village. There are various types of drinks and food available, such as tea, coffee, mineral water, and various types of fried food and bread.

The researcher also observed that there were many food and soft drinks stalls around the field. The competition was started at night after Isya (evening prayer) until 24.00 p.m. even more and the length of the competition was about two months and almost never stopped throughout the year, so that it implicates to the increase of the shopkeepers' income, at an average of Rp. 200,000-Rp. 300,000 for each day.

Balogo is somewhat different if the game is only a friendly match. Generally the host provides drinks and food, and even some hosts provide "heavy" food. The kind of the dish seems to be very dependent on someone's social status. Social status or position of a person in the community gained from his own business is called achieved status [20]. Pelaihari people who have a higher social status always provide "prime" services to the guests. Meals are not just snacks or mineral water but also "heavy foods", such as rice cakes and ketupat which is a Banjarese traditional food.

Besides the stalls, the parking lots are also thrives like mushrooms in the rainy season. The fact is that the participants competing are from outside the village, so that the use of private vehicles has increased. This condition is such a "gold mine" for the "impromptu" park guards.

Logo craftsmen also increased their earnings. Each logo which is made by bringing the raw material itself in the form of ironwood pieces costs Rp. 10,000 per logo, while ordering without bringing raw materials costs Rp. 20,000 per piece. Those prices are used for both "logo pasangan" and "logo undas". According to the logo craftsmen, since this game has been playing since two years ago (2016-2017), they have been producing thousands logos. This condition is an opportunity to increase the economic standard or value of Pelaihari society.

\section{CONCLUSION}

Balogo traditional game contains life values, namely the value of sportsmanship (honesty), cooperation or mutual assistance (kayuh baimbai), competitive, creativity and arts, social values and economic values that appear on the game equipment, procedure of playing the game, and interaction among groups who play it. Social skill becomes a part in balogo traditional game. The excavation of the values of sportsmanship (honesty), competition, cooperation, creativity and the arts, social and economic values will have implications on the national character formation through social science education (IPS) in schools at elementary education 
level (SMP / MTs) as a preparation in facing the challenges and global competition in this era.

This study gives recommendation to the government to preserve the culture of balogo game because it is very identical to the values of life that have strategic functions towards the formation of the national character building. For the social science teachers, it is suggested that they make balogo game as a part of social science education (IPS) learning resources, so the cultural inheritance process continues to run to make the Banjarese younger generation has a concern for their own culture.

\section{REFERENCES}

[1] F. Mutema, "Shona Traditional Children's Games And Songs As A Form of Indigenous Knowledge: An Endangered Genre, IOSR Journal Of Humanities And Social Science (IOSR-JHSS)", Volume 15, Issue 3 (Sep. - Oct. 2013), PP 59-64 e-ISSN: 2279-0837, p-ISSN: 2279-0845, Retrieved from : http://www.iosrjournals.org/iosr-jhss/papers/Vol15issue3/K01535964.pdf?id=7217, Acessed on 10 oktober 2017

[2] F. P. Hughes, Children, Play, and Development, Boston: Allyn and Bacon, 1990.

[3] C. Nikmah and Rudiana, Unesa Journal of Chemical Education, Vol. 5, No. 3, September 2016, pp. 655-661

[4] Iswinarti, "Nilai-Nilai Terapiutik Permainan Tradisional Engklek pada Anak Usia Sekolah Dasar", HUMANITY, Volume 6, Nomor 1, 2010, pp $41-44$

[5] J. A. Banks, Teaching Strategis for Social Studies: Inquiry, Valuing, and Decision Making, Seattle, University of Washington, Addison Wesley Publishing Company, 1990.

[6] C. S. Sunal, and M. E. Haas, Social Studies for The Elementary dan Middle Grades, Boston: Pearson, 1993.

[7] Kemendiknas, "Desain Induk Pembangunan Karakter bangsa Tahun 2010-2025", 2010.

[8] A. Sanusi, Pendidikan Alternatif: Menyentuh Aras Dasar persoalan Pendidikan dan Kemasyarakatan, Bandung: Diterbitkan atas kerjasama PPS IKIP Bandung dan PT. Grafindo Media Pratama, 1998.

[9] Pusat Kurikulum dan Perbukuan (Puskurbuk), Naskah Akademik Kajian Kebijakan Kurikulum Mata pelajaran Ilmu Pengetahuan Sosial (IPS), Jakarta: Depdiknas dan Puskur, 2007.
[10] Peraturan Menteri Pendidikan Nasional (Permendiknas), Nomor 22 Tahun 2006

[11] F. X. Rahyono, Kearifan Budaya dalam Kata, Jakarta: Wedatama Widyasastra, 2009.

[12] H. S. A. Putera, "Ilmuwan Budaya dan Revitalisasi Kearifan Lokal Tantangan Teoritis dan Metodologis", Makalah disampaikan pada Rapat Senat Terbuka Dies Natalis ke-62 Fakultas Ilmu Budaya Universitas Lambung Mangkurat, 2008.

[13] M. B. Miles and Huberman, Michael, Analisis Data Kualitatif, Penerjemah Tjetjep Rohendi Rohidi, Jakarta : Universitas Indonesia Pers, 1992.

[14] J. W. Creswell, Qualitative Inquiry and Research Design, Choosing Among Five Traditions, Thousand Oaks: Sage Publication, 1998.

[15] Denzin \& Lincoln, Handbook of Qualitative Research (terjemahan),Yogyakarta: Pustaka Pelajar, 2009.

[16] C. Snel, The Role of Traditional Children Games Within the Context of Intangible Heritage, 2009 Retrieved from http://www.maltwood.uvic.ca/cam/publications/conference_publication s/Snel.Catherine.GCAM4.pdf, diakses tanggal 10 Oktober 2017

[17] A.R. Hakim, Efektivitas Permainan Tradisional Gobag Sodor Untuk Pembelajaran IPS Kelas IV Sekolah Dasar, Jurnal Bidang Pendidikan Dasar (JBPD), Vol. 1 No. 1, 2017, Tersedia: http://ejournal.unikama.ac.id/index.php/JBPD. Accessed on 24 September 2017

[18] G. W. Maxim, Dinamic Social Studies for Constructivist Calssroom: Inspiring Tomorrow's Social Scientists, New York: Pearson, 2010.

[19] J. W. Santrock, Lifespan Development, Boston: McGraw-Hill College, 2000.

[20] S. Soekanto, Sosiologi: Suatu Pengatar, Jakarta: Raja Grafindo Persada, 2002.

[21] B. Subiyakto, Syaharuddin, Rahman, G, "Nilai Nilai Gotong Royong pada Tradisi Bahaul Dalam Masyarakat Banjar di Desa Andhika Sebagai Sumber Pembelajaran IPS”, Vidya Karya, Volume 31, Nomor 2,2016

[22] Sayidman dan Suryohadiprojo, Budaya Gotong Royong Dan Masa Depan Bangsa, Jakarta: Kompas, 2016.

[23] R. P. Wardani, and Lutfi, "The Development of Benthik Traditional Games as Learning Media for Rehearse Team Work Character on Periodic Table Matter", Unesa Journal of Chemical Education ISSN: 2252-9454 Vol. 3 No 1, 2014, pp 88-92, Retrieved from ejournal.unesa.ac.id/article/9511/36/article.pdf, on 10 Oktober 2017

[24] Tilaar, HAR, Mengindonesia: Etnisitas dan Identitas Bangsa Indonesia, Jakarta: Rineka Cipta, 2007. 